\title{
Water temperature modeling in the Garonne River (France)
}

\author{
K. Larnier ${ }^{(1,2)}$, H. Roux ${ }^{(1,2)}$, D. Dartus ${ }^{(1,2)}$, O. Croze $^{(1,2,3)}$
}

Received May 4, 2010 / Reçu le 4 mai 2010

Revised July 17, 2010 / Révisé le 17 juillet 2010

Accepted July 29, 2010 / Accepté le 29 juillet 2010

Key-words: water

temperature, model, statistical, equilibrium concept, stochastic, migrating fishes

\section{ABSTRACT}

Stream water temperature is one of the most important parameters for water quality and ecosystem studies. Temperature can influence many chemical and biological processes and therefore impacts on the living conditions and distribution of aquatic ecosystems. Simplified models such as statistical models can be very useful for practitioners and water resource management. The present study assessed two statistical models - an equilibrium-based model and stochastic autoregressive model with exogenous inputs - in modeling daily mean water temperatures in the Garonne River from 1988 to 2005. The equilibrium temperature-based model is an approach where net heat flux at the water surface is expressed as a simpler form than in traditional deterministic models. The stochastic autoregressive model with exogenous inputs consists of decomposing the water temperature time series into a seasonal component and a short-term component (residual component). The seasonal component was modeled by Fourier series and residuals by a second-order autoregressive process (Markov chain) with use of short-term air temperatures as exogenous input. The models were calibrated using data of the first half of the period 1988-2005 and validated on the second half. Calibration of the models was done using temperatures above $20^{\circ} \mathrm{C}$ only to ensure better prediction of high temperatures that are currently at stake for the aquatic conditions of the Garonne River, and particularly for freshwater migrating fishes such as Atlantic Salmon (Salmo salar L.). The results obtained for both approaches indicated that both models performed well with an average root mean square error for observed temperatures above $20{ }^{\circ} \mathrm{C}$ that varied on an annual basis from $0.55{ }^{\circ} \mathrm{C}$ to $1.72{ }^{\circ} \mathrm{C}$ on validation, and good predictions of temporal occurrences and durations of three temperature threshold crossings linked to the conditions of migration and survival of Atlantic Salmon.

RÉSUMÉ

Modélisation de la température de l'eau de la Garonne (France)

Mots-clés : température de l'eau,
La température de l'eau est un élément prépondérant pour l'étude de la qualité de l'eau et des écosystèmes. De nombreuses réactions chimiques et biologiques peuvent être influencées par la température qui impacte donc sur les conditions

(1) Université de Toulouse; INPT, UPS; IMFT (Institut de Mécanique des Fluides de Toulouse), Allée Camille Soula, 
modèle, statistique, concept d'équilibre, stochastique, poissons migratoires de viabilité et la distribution spatiale des espèces. Des modèles simples tels que les modèles statistiques peuvent être très utiles pour les gestionnaires et le management des ressources aquatiques. Cette étude visait à étudier la pertinence de deux modèles statistiques - le modèle basé sur la température d'équilibre et le modèle stochastique autorégressif avec facteurs externes - à modéliser les moyennes journalières de température de l'eau de la Garonne sur la période 19882005. Le modèle basé sur la température d'équilibre se base sur la simplification du bilan thermique déterministe prenant en compte les flux à la surface. L'approche stochastique consiste à diviser la série des températures de l'eau en une composante saisonnière et une composante de variations journalières relativement à la composante saisonnière. La composante saisonnière a été modélisée par une décomposition en séries de Fourier et la composante des résidus par un processus autorégressif d'ordre 2 (chaîne de Markov) prenant en compte les résidus des températures de l'air relativement à leur composante saisonnière comme facteur externe. Ces modèles ont été calibrés sur la première moitié de la période 1988-2005 en utilisant les données de température supérieures à $20^{\circ} \mathrm{C}$ pour optimiser les paramètres. Ceci afin de privilégier la restitution des températures élevées qui posent problèmes actuellement pour les écosystèmes aquatiques de Garonne et particulièrement les espèces migratoires comme le Saumon Atlantique (Salmo salar L.). Les résultats obtenus sont très prometteurs avec des erreurstypes calculées pour chaque année qui varient de $0,55^{\circ} \mathrm{C}$ à $1,72{ }^{\circ} \mathrm{C}$ en validation et une bonne restitution des franchissement de trois seuils de températures liées aux conditions de migration et de viabilité de l'espèce Saumon Atlantique.

\section{INTRODUCTION}

Stream water temperature is one of the most important parameters for water quality and ecosystem studies. Temperature can influence many chemical and biological processes such as dissolved oxygen - and therefore impacts on the living conditions and distribution of aquatic ecosystems. The most obvious effects of temperature on aquatic organisms are on their survival and growth rate. For instance, conditions for Atlantic Salmon (Salmo salar L.) particularly depend on water temperature, and high temperatures widely disturb migration of this species (Decola, 1970; Chanseau et al., 1999; Fairchild et al., 1999; Swansburg et al., 2002). Moreover, temperatures above $24^{\circ} \mathrm{C}$ may be considered lethal for this species (Alabaster, 1967; Elliott, 1991; Wilkie et al., 1997).

Understanding the thermal regime of watercourses is therefore very important for management of aquatic resources and fisheries. The thermal regime of a river is governed by many environmental processes (e.g. climatic conditions, topography, etc.) and by some human activities (Caissie, 2006; Webb et al., 2008). Knowledge of the main driving processes of the thermal regime is essential to understand the spatial and temporal variations in the water temperature better.

Ability to predict stream water temperature is also essential in conducting environmental studies and restoration plans. Problems of aquatic species related to water temperatures often happen for high summer temperatures. Predicting time occurrences and duration of the highest temperature periods could be very useful to trigger plans or technical tools to restore favorable aquatic conditions.

To predict water temperatures in streams, many models have been developed and used. These models are often categorized into two major groups: deterministic models and statistical models (Benyahya et al., 2007a). Deterministic models generally consider all relevant heat fluxes between the body of water and both the atmosphere and the bed material (Sinokrot and Stefan, 1994; Kim and Chapra, 1997). Such models are very useful for studies dealing with anthropogenic impacts and changes in inputs (changes in flow regime, watershed restriction, etc.) and distributed deterministic models can predict spatial variations along the watercourse. One major drawback of deterministic models is the need for large amounts of data and computational resources. 
As a result, practitioners prefer to use simplified models such as statistical models. Numerous statistical models have been used in the literature. Among statistical models, regression models have been widely used (Stefan and Preud'homme, 1993; Pilgrim et al., 1998; Erickson and Stefan, 2000) and showed good results in predicting temperature at weekly or monthly time steps, relying on the relatively strong relation between air and water temperature on those time scales (Benyahya et al., 2007a). Most of those models were based on linear regression but in some cases, non-linear regression models have been used for a better description of the change in slope in the relation between air and water temperatures at both low and high air temperature (Mohseni et al., 1998). Although relatively efficient, regression models on a time scale shorter than weekly are more difficult to apply due to autocorrelations in the structure of water temperature time series. In these cases, stochastic models and non-parametric models such as Artificial Neural Networks (ANN) showed better results (Benyahya et al., 2007a; Chenard and Caissie, 2008).

Two particular statistical models - the equilibrium concept-based model and stochastic autoregressive models with exogenous inputs - have shown good efficiency when modeling daily mean water temperatures for large rivers (Caissie et al., 2005; Ahmadi-Nedushan et al., 2007; Benyahya et al., 2007b). These two models only use air temperature as a predictor and therefore the relation between air and water temperatures was to be assessed.

The objectives of this study were (a) to assess the influence of climatic conditions on water temperatures in the Garonne River in order to verify that air temperature is the main factor that has influenced the thermal regime of the Garonne River for the past two decades, and (b) to assess the efficiency of two statistical models to predict daily mean water temperatures, and particularly the high summer peaks that are currently an issue for aquatic ecology.

\section{METHODOLOGY}

\section{> TRENDS AND CORRELATIONS}

The first step of our study was to analyze trends in the evolution of stream water temperatures, and hydraulic and climatic parameters to determine parameters potentially related to the thermal regime evolution of the Garonne River. Analyses of trends in descriptive statistics of the time series (annual percentiles, annual and seasonal averages) were performed and related significances were assessed using the non-parametric Spearman rank correlation test. Afterwards, correlation analyses were performed between water temperatures and parameter statistics that presented significant trends.

\section{$>$ WATER TEMPERATURE MODELS}

\section{Equilibrium concept}

Deterministic models in previous studies (Raphael, 1962; Sinokrot and Stefan, 1984; Morin and Couillard, 1990) have established the relevant energy components of heat exchange in rivers. The one-dimensional law of conservation of energy for vertically well-mixed streams is expressed as follows:

$$
\frac{\partial T_{\mathrm{w}}}{\partial t}+u \frac{\partial T_{\mathrm{w}}}{\partial x}-\frac{1}{A} \frac{\partial}{\partial x}\left(A \cdot D_{\mathrm{L}} \frac{\partial T_{\mathrm{w}}}{\partial x}\right)=\frac{B}{\rho \cdot C_{\mathrm{w}} \cdot A} S_{\mathrm{t}}+\frac{P}{\rho \cdot C_{\mathrm{w}} \cdot A} S_{\text {bed }}
$$

where $T_{\mathrm{w}}$ is the water temperature $\left({ }^{\circ} \mathrm{C}\right), t$ the time (day), $x$ the longitudinal distance downstream $(\mathrm{m}), u$ the mean water velocity $\left(\mathrm{m} \cdot \mathrm{s}^{-1}\right), A$ the cross-sectional area $\left(\mathrm{m}^{2}\right), D_{\mathrm{L}}$ the longitudinal diffusive coefficient in direction of flow $\left(\mathrm{m}^{2} \cdot \mathrm{s}^{-1}\right), B$ the width of the free surface, $\rho$ the water density $\left(1000 \mathrm{~kg} \cdot \mathrm{m}^{-3}\right), C_{\mathrm{w}}$ the specific heat of the water $\left(4.85 \times 10^{-2} \mathrm{~W} \cdot \mathrm{kg}^{-1} \cdot{ }^{\circ} \mathrm{C}^{-1}\right), S_{\mathrm{t}}$ the net heat flux from the atmosphere to the river $\left(\mathrm{W} \cdot \mathrm{m}^{-2}\right), P$ the wetted perimeter $(\mathrm{m})$ and $S_{\text {bed }}$ the heat flux with the streambed $\left(\mathrm{W} \cdot \mathrm{m}^{-2}\right)$. 
When dealing with water temperature on a daily basis or for longer time steps, the streambed heat flux can be neglected (Morin and Couillard, 1990; Sinokrot and Stefan, 1994). Furthermore, changes in temperatures along river reaches have been reported to be usually small compared with diurnal variation for river reaches with fairly uniform water temperature (Torgersen et al., 2001). In such cases, the diffusive and convective terms can be neglected in equation (1), which then can be simplified to the following form:

$$
\frac{\partial T_{\mathrm{w}}}{\partial t}=\frac{B}{\rho \cdot C_{\mathrm{w}} \cdot A} S_{\mathrm{t}}
$$

where the parameters were defined previously. Equation (2) has been used in many studies to estimate water temperatures at specific locations of various streams using meteorological data (Marcotte and Duong, 1973; Morin and Couillard, 1990). Moreover, equation (2) can be used to estimate the upstream temperatures when conducting one-dimensional water temperature modeling (Sinokrot and Stefan, 1993).

The net heat flux $S_{t}$ is a compound of net solar radiation, net long wave radiation, convection and evaporation and thus can be expressed using meteorological data only. Studies dealing with modeling the thermal regime of rivers have, however, shown that the net heat flux can be expressed in a simpler form using the equilibrium temperature concept (Edinger et al., 1968; Morin and Couillard, 1990). The equilibrium temperature stands for the water temperature leading to a null total heat flux $\left(S_{\mathrm{t}}\left(T_{\mathrm{e}}\right)=0\right.$ where $T_{\mathrm{e}}$ is the equilibrium temperature $\left.\left({ }^{\circ} \mathrm{C}\right)\right)$. Hence, the equilibrium temperature is a function of meteorological parameters. Methods for calculating the equilibrium temperature can be found in Mohseni and Stefan (1999) and Caissie et al. (2005). If such a temperature can be calculated, the net heat flux can be expressed using Newton's law of cooling:

$$
S_{\mathrm{t}}=K\left(T_{\mathrm{e}}-T_{\mathrm{w}}\right)
$$

where $K$ is a thermal exchange coefficient $\left(\mathrm{W} \cdot \mathrm{m}^{-2} \cdot{ }^{\circ} \mathrm{C}^{-1}\right)$.

Using equation (3), equation (2) can be rewritten:

$$
\frac{\partial T_{\mathrm{w}}}{\partial t}=\frac{B \cdot K}{\rho \cdot C_{\mathrm{w}} \cdot A}\left(T_{\mathrm{e}}-T_{\mathrm{w}}\right)
$$

Influences of different physical and meteorological parameters can therefore be evaluated using the equilibrium temperature concept, as reported in Mohseni and Stefan (1999), which is one particular advantage of this concept.

Furthermore, although the equilibrium temperature is a function of many meteorological parameters, it can be reduced in temperate regions to a function of air temperature only. Indeed, strong linear association between the equilibrium temperature and air temperature can be postulated in such regions (Mohseni and Stefan, 1999). Using this hypothesis, equation (4) can be rewritten using air temperature (Caissie et al., 2005):

$$
\frac{\partial T_{\mathrm{w}}}{\partial t}=K^{\prime} \frac{\left(a_{1} T_{\mathrm{a}}+a_{2}-T_{\mathrm{w}}\right)}{h}
$$

where $a_{1}$ and $a_{2}$ are the coefficients of the linear regression between the air temperature and equilibrium temperature, $K^{\prime}=K /\left(\rho \cdot C_{\mathrm{w}}\right)$ the modified exchange coefficient $\left(\mathrm{s}^{-1}\right)$ and $B / A$ is approximated by $1 / h$ where $h$ is the water depth $(\mathrm{m})$. Where water depths are not monitored, $h$ can be estimated as a function of discharge: $h=a Q^{b}$ (Leopold et al., 1964).

The equilibrium temperature values for the days where all needed meteorological data were available (from 1992 to 2005) were first calculated and the linear association between air and equilibrium temperatures was assessed. Once this association was verified, equation (5) was used to establish the model which will be further referred to as the EQB model.

\section{Stochastic autoregressive models with exogenous inputs}

Stochastic autoregressive models consist of splitting water temperature series into two components that are then modeled adequately. For instance, water temperature may be divided 
as follows:

$$
T_{\mathrm{w}}(t)=T A_{\mathrm{w}}(t)+R_{\mathrm{w}}(t)
$$

The first component is the long-term annual component and represents the seasonal variations, and the second (residuals from the annual component) represents the short-term variations which are stationary. Using this approach a time series model can be fitted to water temperature residuals. Numerous time series models can be found in the literature such as Box-Jenkins, AR, ARMA, PAR, etc. (Benyahya et al., 2007a, 2007b).

The seasonal component is often modeled by a Fourier series analysis (Kothandaraman, 1971; El-Jabi et al., 1995) or even a simpler sinusoidal function (Cluis, 1972; Caissie et al., 1998). In this paper the Fourier series analysis was used to model both the air and water temperature seasonal components. Thus, these two functions are expressed as follows:

$$
T A(t)=\bar{T}+\sum_{k=1}^{\infty}\left(\chi_{k}\left[\cos \left(\left(t-j_{T}+1\right) \frac{2 \pi k}{N_{T}}+\phi_{k}\right)\right]\right)
$$

where $\bar{T}$ is the mean - water or air - temperature of the period $T, k$ is the order of each harmonic of the Fourier analysis, $j_{T}$ is the rank of the first day where data is available in the period $T, N_{T}$ is the number of days of the period $T$ and $\chi_{k}$ and $\phi_{k}$ are, respectively, the amplitude and the phase of each harmonic:

$$
\begin{aligned}
& \chi_{k^{2}}=A_{k^{2}}+B_{k^{2}} \\
& \cos \left(\phi_{k}\right)=A_{k} / \chi_{k}
\end{aligned}
$$

where $A_{k}$ and $B_{k}$ are Fourier coefficients that are expressed as follows:

$$
\begin{aligned}
& A_{k}=\frac{2}{N_{T}} \sum_{t=1}^{N_{T}}\left(T(t) \cos \left(\frac{2 \pi k t}{N_{T}}\right)\right) \\
& B_{k}=\frac{2}{N_{T}} \sum_{t=1}^{N_{T}}\left(T(t) \sin \left(\frac{2 \pi k t}{N_{T}}\right)\right) .
\end{aligned}
$$

Using the first harmonic $(k=1)$ to describe the long-term variations in air and water temperatures showed only small losses, and using the first two harmonics $(k=(1,2))$ is sufficient, as reported by Kothandaraman (1971). Moreover, Kothandaraman also reported that up to $95 \%$ of the deviance can be explained by seasonal variations for water temperatures and up to $80 \%$ for air temperatures.

The residuals of the water temperatures were modeled by a second-order Markov process as suggested by Cluis (1972). The general form of the complete model is as follows:

$$
R_{\mathrm{w}}(t)=A_{1} R_{\mathrm{w}}(t-1)+A_{2} R_{\mathrm{w}}(t-2)+K R_{a}(t)+\varepsilon_{1}(t)
$$

where $A_{1}=R_{1}\left(1-R_{2}\right) /\left(1-R_{1}^{2}\right)$ and $A_{2}=\left(R_{2}-R_{1}^{2}\right) /\left(1-R_{1}^{2}\right)$ with $R_{1}$ and $R_{2}$ the autocorrelation coefficients for lags of 1 and 2 days. $\varepsilon_{1}$ is the residual estimation error for this model and $K$ represents the linear regression coefficient between the remaining residuals of the Markov process and the residuals of air temperature after removing the seasonal component, also referred to as the thermal exchange coefficient. This coefficient depends on many parameters such as stream cover, depth of water, etc. The value of this coefficient was estimated by the method of least squares. This model will be further referred to as the SMP1 model.

Equation (8) only takes into account the residual of air temperatures with no lag. However, Kothandaraman (1971) reported that residuals of air temperature with lags of up to two days were significant in explaining the evolution of water temperature residuals on a daily basis. Thus, the third model used in this study - which will be further referred to as SMPM - extends the Cluis approach by taking lagged air temperatures as predictors. The formulation of this model is therefore:

$$
R_{\mathrm{w}}(t)=A_{1} R_{\mathrm{w}}(t-1)+A_{2} R_{\mathrm{w}}(t-2)+\sum_{i=1}^{p} K_{i} R_{a}(t-i)+\varepsilon_{2}(t)
$$


where $\varepsilon_{2}$ is the residual estimation error for this model and $K_{i}$ represents the linear regression coefficient between the residuals of the Markov process and the residuals of air temperatures with a lag of $i$ day(s). The maximum lag taken into account $p$ was first estimated using crosscorrelation analysis between the residuals of the Markov process and the residuals of air temperature, and finally determined using the AIC criterion (Akaike, 1974). The method of least squares was used to estimate the values of the $K_{i}$.

The SMP1 and SMPM models only required water temperature and air temperature time series, which were available for the whole period 1978-2005. To conduct a fair comparison between these models and the equilibrium-based model, the same calibration and validation periods were used.

\section{Model calibration and performance assessment}

The data needed to establish all models were available for the years 1988 to 2005 . This period was split into calibration and validation periods; respectively, 1988-1996 and 1997-2005. Data of the first part (1988-1996) were used to calibrate the models. Parameters were optimized using the least-squares method and using only data where observed temperatures were above $20^{\circ} \mathrm{C}$ to ensure better performance for high temperature prediction. The remaining years' (1997-2005) data were afterwards used for validation of the models.

To assess the performance of each model in predicting the daily mean water temperatures, the root mean square error criterion was used (RMSE (Berger, 1985)) that is calculated by:

$$
\mathrm{RMSE}=\sqrt{\frac{\sum_{i=1}^{N}\left(T_{i}^{\mathrm{OBS}}-T_{i}^{\mathrm{PRE}}\right)^{2}}{N}}
$$

where $N$ is the number of observations, $T_{i}^{\mathrm{OBS}}$ the observed daily mean water temperatures and $T_{i}^{\mathrm{PRE}}$ the predicted daily mean water temperatures.

Another criterion was used during the validation step that is more related to the conditions of salmon migration and viability. Three important temperature thresholds were selected that reflect migrating conditions: $9^{\circ} \mathrm{C}, 19^{\circ} \mathrm{C}$ and $24^{\circ} \mathrm{C}$. Chanseau et al. (1999) showed that $9{ }^{\circ} \mathrm{C}$ and $24^{\circ} \mathrm{C}$ are, respectively, the lower and upper limits for salmon migration, with no passage at fish passage facilities for lower or higher temperatures. Above $24^{\circ} \mathrm{C}$, salmons are sensitive to thermal stress and most of the salmon mortalities in the Garonne River were recorded for such temperatures (Croze et al., 2006). The last temperature threshold $\left(19^{\circ} \mathrm{C}\right)$ was reported as the upper limit for optimal conditions for youth growth (Decola, 1970; Swansburg et al., 2002). The performance of each model regarding these thresholds was assessed by comparing the temporal occurrence and duration of periods between consecutive thresholds of observed and predicted time series.

\section{DATA AND STUDY AREA}

\section{> STUDY AREA}

The study area is located on the Garonne River at the Malause reservoir, upstream of the headrace of the Golfech nuclear power plant (Figure 1). The water thermal regime in this location is influenced by climatic conditions, and the Tarn tributary which has a junction with the Garonne River is located $5 \mathrm{~km}$ upstream of the study site. The climate is temperate and characterized by mostly gentle winters and hot summers. The Garonne between Toulouse and the study site is a well-mixed, wide and shallow river; therefore profiles of water temperatures were assumed to be laterally and vertically uniform. 


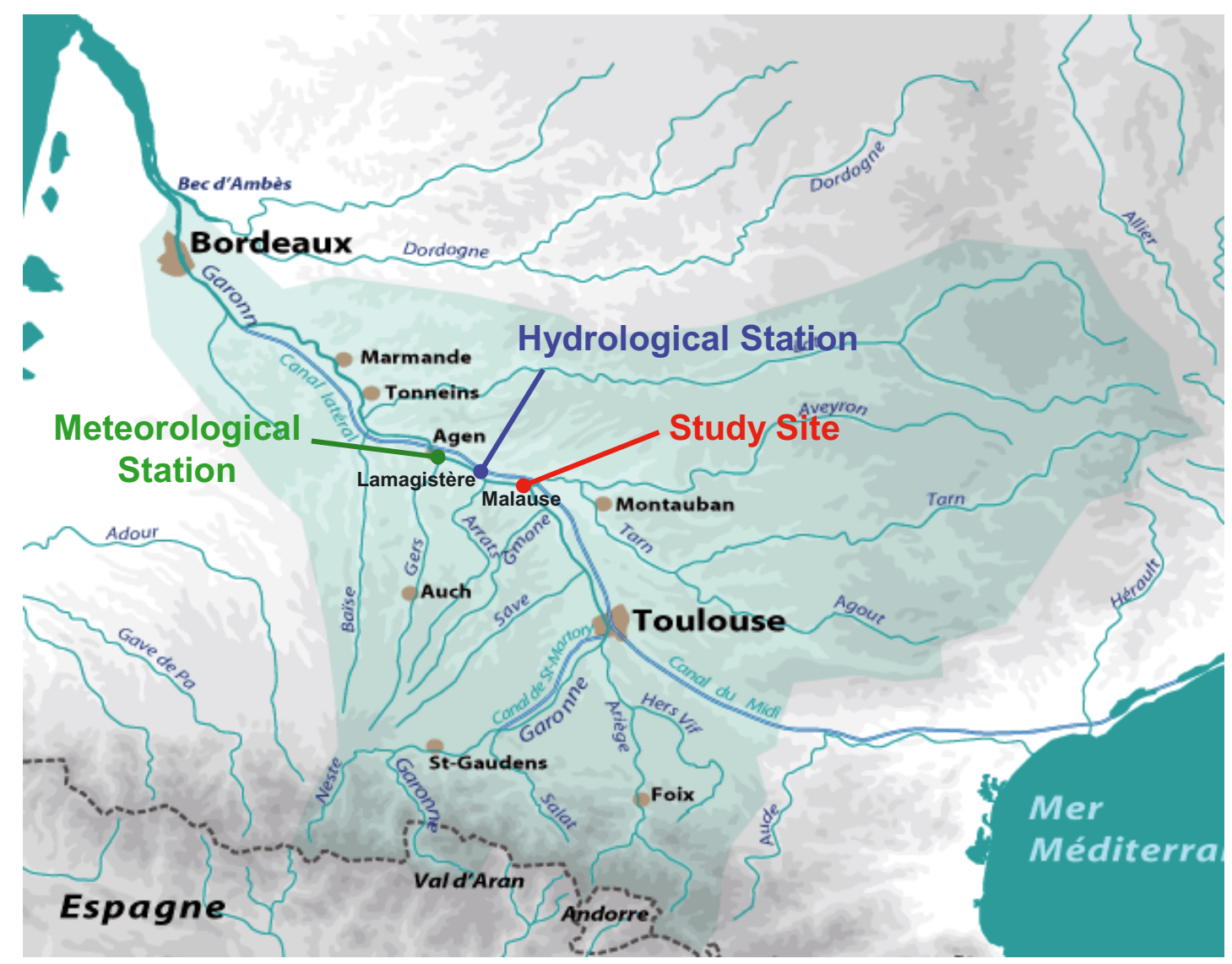

\section{Figure 1}

Study site and locations of data stations. Adapted from EPTB Garonne website (http://www. eptb-garonne.fr).

\section{Figure 1}

Zone d'étude et localisation des stations de données - d'après une carte disponible sur le site de l'EPTB Garonne.

\section{Data}

Along our study reach a large amount of climatic and hydrologic data was gathered. Daily mean water temperature series in Malause were available from 1978 to 2005 from measurements in the headrace of the Golfech nuclear power plant performed by EDF ${ }^{1}$. Hydrological data were available at the Lamagistère station of the Banque $\mathrm{HYDRO}^{2}$ that is $17 \mathrm{~km}$ downstream of Malause. Mean daily discharges were available from 1967 with no uncertain or missing data and mean daily water levels from 1988 with about $1 \%$ of uncertain data and less than $0.01 \%$ of missing data. Three-hourly meteorological data were gathered at the Agen and Blagnac weather stations of Météo-France ${ }^{3}$. Air temperatures were available at both stations for the years 1978 to 2005 with less than $0.01 \%$ of missing or uncertain data. Incident solar radiation (also referred to as insolation) data were only available at the Agen station, with few missing data (0.2\%) from 1978 to 2005 . Cloud cover and wind speed were only available at the Blagnac station from 1992 but with numerous uncertain or missing data. Cloud cover uncertain data were about $8 \%$ (no missing data) and the wind speed time series presents

1 Électricité de France, http://www.edf.fr.

2 Banque HYDRO, http://www.hydro.eaufrance.fr.

3 Météo-France, http://www.meteofrance.com. 
Table I

Availability and consistency of daily mean data.

Tableau I

Disponibilité et qualité des données de moyennes journalières obtenues.

\begin{tabular}{|l|c|c|c|c|c|c|}
\hline & Station & Availability & Validate & Doubtful & Missing & Producer \\
\hline Discharge & Lamagistère & $1967-2005$ & $100 \%$ & $0 \%$ & $0 \%$ & Banque HYDRO \\
\hline Water level & Lamagistère & $1988-2005$ & $100 \%$ & $0 \%$ & $0 \%$ & Banque HYDRO \\
\hline Water temperature & Malause & $1978-2005$ & $100 \%$ & $0 \%$ & $0 \%$ & EDF \\
\hline Air temperature & Blagnac & $1978-2006$ & $100 \%$ & $0 \%$ & $0 \%$ & Météo-France \\
\hline Air temperature & Agen & $1978-2006$ & $100 \%$ & $0 \%$ & $0 \%$ & Météo-France \\
\hline Incoming solar radiation & Agen & $1978-2005$ & $100 \%$ & $0 \%$ & $0 \%$ & Météo-France \\
\hline Nebulosity & Blagnac & $1992-2005$ & $100 \%$ & $0 \%$ & $0 \%$ & Météo-France \\
\hline Wind speed & Blagnac & $1992-2005$ & $96 \%$ & $4 \%$ & $0 \%$ & Météo-France \\
\hline
\end{tabular}

\section{Table II}

Analysis of trends and significance ( $p$-value) in water temperatures and climatic parameters with significant trends.

\section{Tableau II}

Analyse en tendances des chroniques des températures de l'eau et des paramètres climatiques, et significativités correspondantes ( $p$-value).

\begin{tabular}{|l|c|c|c|c|c|c|}
\hline & \multicolumn{2}{|c|}{ Water temperature } & \multicolumn{2}{c|}{ Air temperature } & \multicolumn{2}{c|}{ Incident solar radiation } \\
\hline & Evolution & $p$-Value & Evolution & $p$-Value & Evolution & $p$-Value \\
\hline 5th percentile & - & 0.493 & - & 0.098 & - & 0.467 \\
\hline 95th percentile & $+2.12^{\circ} \mathrm{C}$ & 0.010 & $+2.79^{\circ} \mathrm{C}$ & 0.000 & - & 0.078 \\
\hline Annual average & $+1.29^{\circ} \mathrm{C}$ & 0.007 & $+1.58^{\circ} \mathrm{C}$ & 0.000 & $+28 \mathrm{~J} \cdot \mathrm{cm}^{-2}$ & 0.029 \\
\hline Winter average & - & 0.338 & - & 0.203 & - & 0.283 \\
\hline Spring average & $+1.60^{\circ} \mathrm{C}$ & 0.003 & $+2.15^{\circ} \mathrm{C}$ & 0.000 & $+55 \mathrm{~J} \cdot \mathrm{cm}^{-2}$ & 0.010 \\
\hline Summer average & $+2.92^{\circ} \mathrm{C}$ & 0.001 & $+2.57^{\circ} \mathrm{C}$ & 0.000 & - & 0.112 \\
\hline Fall average & - & 0.446 & - & 0.061 & - & 0.631 \\
\hline
\end{tabular}

numerous uncertain and missing data (about $4 \%$ each), with six non-consecutive months of missing data. All meteorological data were aggregated in daily means. Availability of daily means data for all parameters is summarized in Table I.

\section{RESULTS}

\section{> TRENDS AND CORRELATION}

Trend analyses of seven descriptive statistics of water temperatures, and hydraulic and climatic parameter time series were performed: 5th and 95th annual percentiles, and annual and seasonal averages. Cloud cover, wind speed and hydraulic parameters showed no significant trend at all. The results for the remaining parameters are listed in Table II and respective evolutions are plotted in Figure 2. Significant trends at the 99\% confidence interval $(p<0.01)$ were found for the 95th percentile and for the annual, spring and summer averages of both air and water temperatures. The annual averages of water temperatures in Malause have risen by $1.29{ }^{\circ} \mathrm{C}$ and summer averages by $2.92{ }^{\circ} \mathrm{C}$. Air temperatures showed similar trends, with annual averages that have risen by $1.58{ }^{\circ} \mathrm{C}$ and summer averages by $2.57{ }^{\circ} \mathrm{C}$. Significant trends for insolation were only found for the annual and spring averages, with rises of $28 \mathrm{~J} \cdot \mathrm{cm}^{-2}$. day ${ }^{-1}$ and $55 \mathrm{~J} \cdot \mathrm{cm}^{-2} \cdot$ day $^{-1}$, respectively.

Correlation analyses on water temperatures against air temperatures and incident solar radiation were performed afterwards for the four descriptive statistics with significant trends. Analyses were performed using one parameter at a time (Table III). At the 99\% confidence 

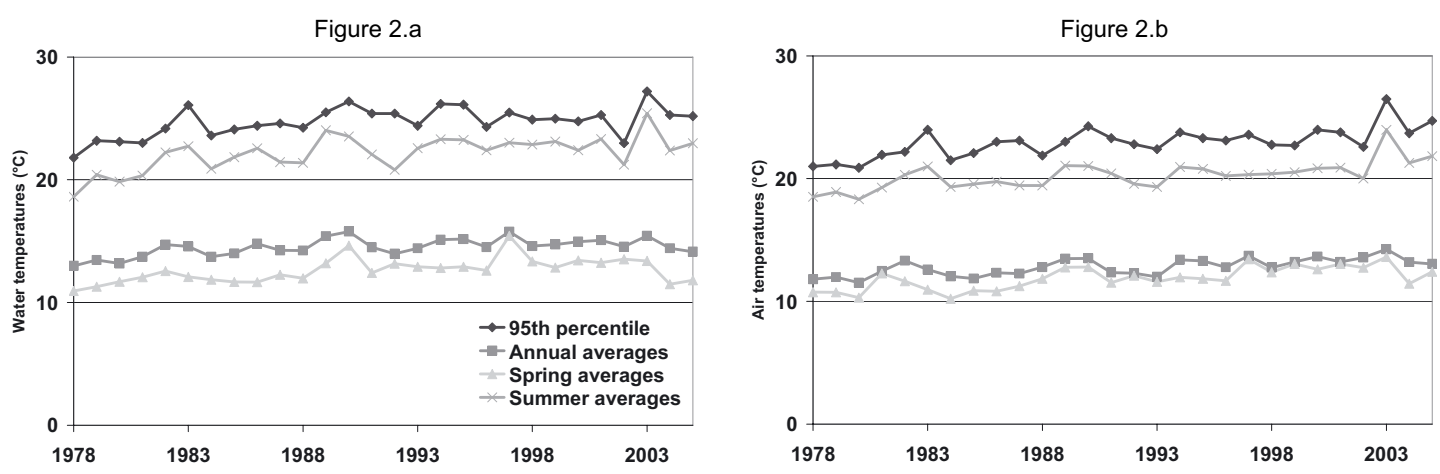

Figure 2.c

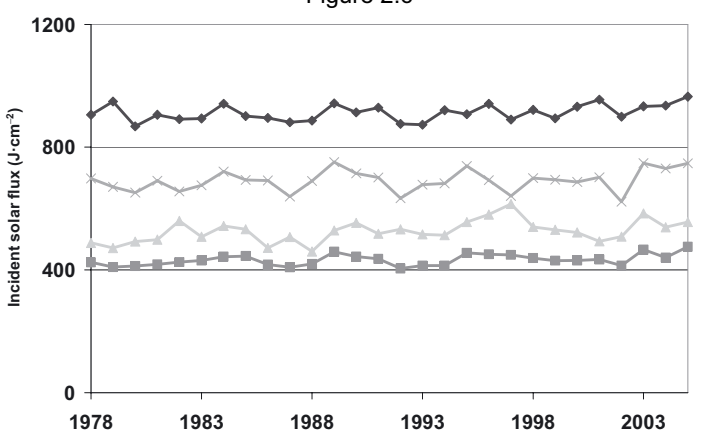

\section{Figure 2}

Trends in water temperatures in Malause (Figure 2.a), air temperatures (Figure 2.b) and incident solar radiation (Figure 2.c) at the Agen station.

\section{Figure 2}

Tendance d'évolution des températures de l'eau à Malause (Figure 2.a), des températures de l'air (Figure 2.b) et de la radiation solaire à Agen (Figure 2.c).

\section{Table III}

Analysis of correlations and significance of water temperatures against air temperatures and incident solar radiation.

Tableau III

Analyse des corrélations des températures de l'air et de la radiation solaire incidente avec les températures de l'eau, et significativités correspondantes.

\begin{tabular}{|l|c|c|c|c|}
\hline & \multicolumn{2}{|c|}{ Air temperature } & \multicolumn{2}{c|}{ Incident solar radiation } \\
\hline & Correlation & $p$-Value & Correlation & $p$-Value \\
\hline 95th percentile & 0.85 & 0.000 & - & 0.344 \\
\hline Annual average & 0.83 & 0.000 & - & 0.507 \\
\hline Spring average & 0.78 & 0.000 & 0.58 & 0.001 \\
\hline Summer average & 0.87 & 0.000 & 0.48 & 0.010 \\
\hline
\end{tabular}

interval, air temperature was the most significant predictor, that explained more than $75 \%$ of the variance of the water temperature descriptive statistics. Regarding high water temperatures (summer averages or the 95th percentile), air temperatures explained more than $85 \%$ of the variance. The lowest calculated correlation coefficient was for spring averages $\left(R^{2}=0.78\right)$. Insolation was significantly correlated with water temperatures only for spring averages and summer averages (at the $99 \%$ confidence interval) but with correlation coefficients of less than 0.60 . The best correlation coefficient was obtained for spring averages $\left(R^{2}=0.58, p=0.001\right)$. 
Table IV

RMSE $\left({ }^{\circ} \mathrm{C}\right)$ calculated from observed and predicted daily mean water temperatures using the EQB model for the years 1988-2005 in Malause.

\section{Tableau IV}

Erreurs-types $\left({ }^{\circ} \mathrm{C}\right)$ calculées entre les observations des températures moyennes journalières de l'eau et les estimations fournies par le modèle EQB sur la période 1988-2005.

\begin{tabular}{|c|c|c|c|c|c|}
\hline & Whole year & $T_{\mathrm{w}}^{\mathrm{OBS}}>20^{\circ} \mathrm{C}$ & & Whole year & 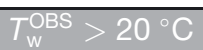 \\
\hline 1988 & 1.43 & 0.68 & 1997 & 1.23 & 1.06 \\
\hline 1989 & 1.17 & 0.71 & 1998 & 1.07 & 0.76 \\
\hline 1990 & 0.89 & 0.78 & 1999 & 1.11 & 0.61 \\
\hline 1991 & 1.19 & 0.81 & 2000 & 1.25 & 1.07 \\
\hline 1992 & 1.54 & 0.71 & 2001 & 1.05 & 0.84 \\
\hline 1993 & 1.35 & 1.15 & 2002 & 1.40 & 1.21 \\
\hline 1994 & 1.10 & 0.65 & 2003 & 1.56 & 1.74 \\
\hline 1995 & 0.89 & 0.53 & 2004 & 1.41 & 1.41 \\
\hline 1996 & 1.26 & 1.03 & 2005 & 1.61 & 1.72 \\
\hline $1988-1996$ & 1.22 & 0.81 & 1997-2005 & 1.31 & 1.22 \\
\hline \multicolumn{3}{|c|}{ Calibration period } & \multicolumn{3}{|c|}{ Validation period } \\
\hline
\end{tabular}

\section{> EQUILIBRIUM TEMPERATURE-BASED MODEL}

Mean daily equilibrium temperatures showed a strong linear relation with daily mean air temperatures in Malause, with a calculated value of $R^{2}=0.99$. The EQB model was therefore calibrated using data from the calibration period (1988-1996). The coefficients of the linear regression between estimated daily mean equilibrium temperatures and daily mean air temperatures were estimated as $a_{1}=1.12$ and $a_{2}=0.44{ }^{\circ} \mathrm{C}$. Using these values, the modified thermal coefficient was calculated at $K^{\prime}=0.56 \mathrm{~s}^{-1}$.

On both the calibration period and validation period, RMSE were calculated for the overall period and for each year, both using all data and data with high observed daily mean water temperatures (above $20^{\circ} \mathrm{C}$ ) only (Table IV). On the calibration period, the overall RMSE was calculated at $1.22{ }^{\circ} \mathrm{C}$ and $0.81{ }^{\circ} \mathrm{C}$ for temperatures above $20^{\circ} \mathrm{C}$. Inter-annual comparison showed that the RMSE ranged from $0.89^{\circ} \mathrm{C}(1990,1995)$ to $1.54{ }^{\circ} \mathrm{C}(1992)$ using all data and $0.53^{\circ} \mathrm{C}$ (1995) to $1.15^{\circ} \mathrm{C}(1993)$ for temperatures above $20^{\circ} \mathrm{C}$. On the validation period, the RMSE was calculated at $1.31^{\circ} \mathrm{C}$. Values calculated for each year ranged from $1.05^{\circ} \mathrm{C}(2001)$ to $1.61{ }^{\circ} \mathrm{C}$ (2005). Regarding temperatures above $20^{\circ} \mathrm{C}$ only, the RMSE ranged from $0.61^{\circ} \mathrm{C}$ (1999) to $1.72{ }^{\circ} \mathrm{C}(2005)$ with an overall value calculated at $1.22{ }^{\circ} \mathrm{C}$. The fitness of the results can also be assessed in Figure 4. The model showed good agreement on temperatures above $20{ }^{\circ} \mathrm{C}$, except for the year 2005 where temperatures around day 180 were overpredicted. Overpredictions were also noted for temperatures just below $20^{\circ} \mathrm{C}$, as for spring of the year 1998.

\section{> STOCHASTIC MODELS}

The values calculated for $\chi_{k}$ and $\phi_{k}$ for the first two harmonics of equation (7) are listed in Table V. Comparison of the seasonal components of water and air temperatures indicated that water temperatures - apart from short-term variations - are always higher than air temperatures (see Figure 3). Moreover, the relation between interannual means was $\overline{T_{\mathrm{w}}}=1.12 \overline{T_{\mathrm{a}}}+0.37$. The seasonal component of water temperatures explained $92 \%$ of the deviance in the period 1988-1996 and 84\% in the period 1997-2005. Regarding air temperatures, the proportion of deviance explained by the seasonal components was $76 \%$ in the period $1988-1996$ and $70 \%$ in the period 1997-2005. These values agree with those reported by Kothandaraman (1971). The maximum temperature for the long-term component of the stream water temperature was reached on day 226 (August 14) at a value of $23.8^{\circ} \mathrm{C}$. 


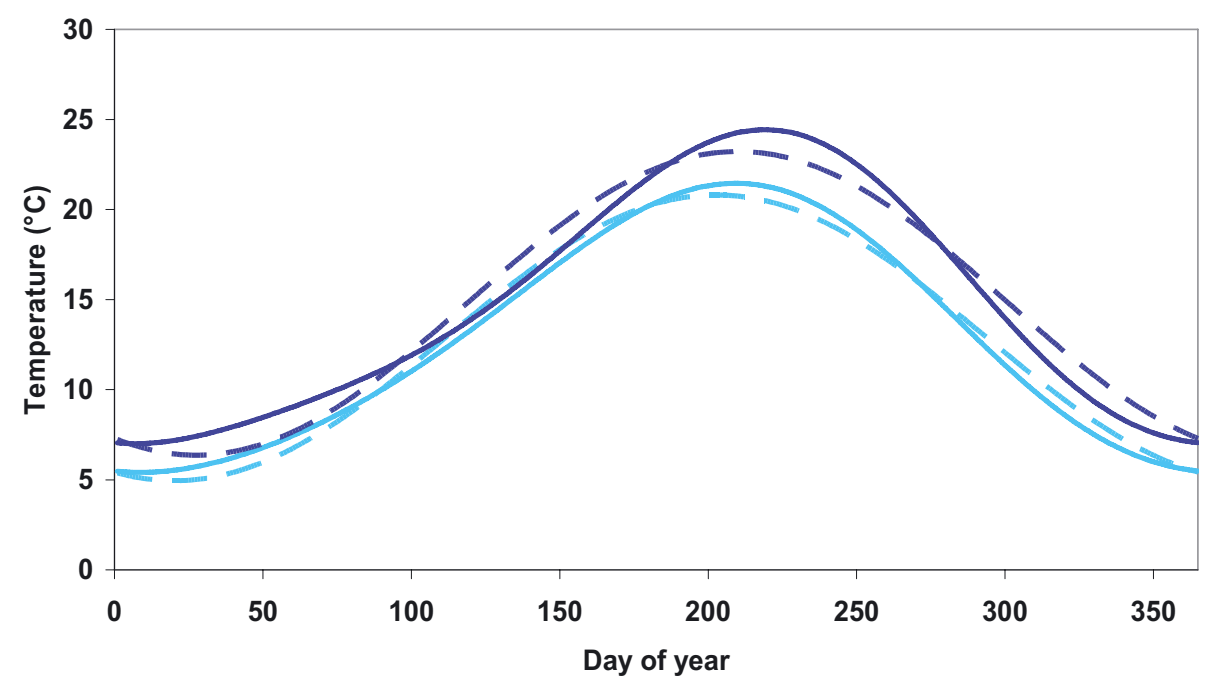

$$
\begin{array}{|l}
\hline-- \text { Air temperature - 1st harmonic }- \text { Air temperature - seasonal } \\
-- \text { Water temperature - 1st harmonic }- \text { Water temperature - seasonal }
\end{array}
$$

\section{Figure 3}

First harmonics and complete seasonal components in air and water temperatures.

\section{Figure 3}

Composantes saisonnières des chroniques de températures de l'air et de l'eau (complètes et premières harmoniques seules).

Once the long-term variations were removed from the water temperature time series, the SMP1 and SMPM models were fitted on the residuals. The autocorrelation coefficients for the water temperature residuals were calculated at $R_{1}=0.97$ and $R_{2}=0.91$. The Markov coefficients were therefore calculated at $A_{1}=1.54$ and $A_{2}=-0.58$.

The thermal exchange coefficient of the SMP1 model was then calculated as 0.049 using data for the validation period (1988-1996). The SMP1 model is therefore expressed as follows:

$$
R_{\mathrm{w}}(t)=1.54 R_{\mathrm{w}}(t-1)-0.58 R_{\mathrm{w}}(t-2)+0.049 R_{\mathrm{a}}(t)+\varepsilon_{1}(t) .
$$

Root mean square errors between predicted and observed values were calculated on the calibration period as well as for each year and for high observed water temperatures (Tables VI and VII). The RMSE was calculated as $1.13{ }^{\circ} \mathrm{C}$ when using all data and $0.95{ }^{\circ} \mathrm{C}$ for high temperatures. Overall results were better than those obtained with the EQB model but RMSE calculated for high temperatures were a little bit higher. Results also varied from year to year, with the RMSE ranging from $0.87^{\circ} \mathrm{C}(1994)$ to $1.35^{\circ} \mathrm{C}(1988)$ for overall data and from $0.49^{\circ} \mathrm{C}$ (1995) to $1.32{ }^{\circ} \mathrm{C}(1993)$ for high temperatures. On the validation period, the RMSE ranged from $1.11^{\circ} \mathrm{C}(1999,2001)$ to $1.49^{\circ} \mathrm{C}(2005)$ using all data and from $0.72{ }^{\circ} \mathrm{C}(1999)$ to $1.72{ }^{\circ} \mathrm{C}$ (2003) for temperatures above $20^{\circ} \mathrm{C}$, with values of $1.27^{\circ} \mathrm{C}$ calculated on the whole validation period using both all data and temperatures above $20^{\circ} \mathrm{C}$.

To establish the SMPM model, cross-correlation analysis between the residuals of the Markov process and the residuals of air temperatures revealed an exponential decrease in the crosscorrelation coefficient when increasing the lag. The cross-correlation coefficients calculated for lags of 0 to 3 days were, respectively, $0.53,0.41,0.32$ and 0.25 . The analyses of the AIC criterion and significance of the regression coefficients showed that lags higher than 3 days were insignificant. Finally, the SMPM model is expressed as follows:

$$
\begin{aligned}
& R_{\mathrm{w}}(t)=1.54 R_{\mathrm{w}}(t-1)-0.58 R_{\mathrm{w}}(t-2)+0.045 R_{\mathrm{a}}(t) \\
& +0.035 R_{\mathrm{a}}(t-1)-0.032 R_{\mathrm{a}}(t-2)-0.014 R_{\mathrm{a}}(t-3)+\varepsilon_{2}(t) .
\end{aligned}
$$

This model clearly provided better results than the SMP1 model (Table VII). Moreover, it fitted better than the EQB model on the whole time series with the RMSE calculated at $1.04{ }^{\circ} \mathrm{C}$ 
Table $V$

Coefficient values of seasonal (Eq. (10)) components for air and water temperatures.

Tableau V

Coefficients des composantes saisonnières (Éq. (7)) des chroniques de températures de l'air et de l'eau.

\begin{tabular}{|c|c|c|}
\hline & Water temperature & Air temperature \\
\hline$\chi_{\mathbf{1}}$ & 8.43 & 7.93 \\
\hline$\phi_{\mathbf{1}}$ & 2.67 & 2.79 \\
\hline$\chi_{\mathbf{2}}$ & 1.48 & 0.84 \\
\hline$\phi_{\mathbf{2}}$ & -1.73 & -1.50 \\
\hline
\end{tabular}

\section{Table VI}

RMSE $\left({ }^{\circ} \mathrm{C}\right)$ calculated from observed and predicted daily mean water temperatures using the SMP1 model and the SMPM model for the years 1988-2005 in Malause.

\section{Tableau VI}

Erreurs-types $\left({ }^{\circ} \mathrm{C}\right)$ calculées entre les observations des températures moyennes journalières de l'eau et les estimations fournies par les modèle SMP1 et SMPM sur la période 1988-2005.

\begin{tabular}{|l|c|c|c|c|c|}
\hline & \multicolumn{2}{|c|}{ SMP1 } & \multicolumn{2}{|c|}{ SMPM } & \\
\hline & All data & $T_{W}^{\mathrm{OBS}}>20^{\circ} \mathrm{C}$ & All data & $T_{\mathrm{W}}^{\mathrm{OBS}}>2{ }^{\circ} \mathrm{C}$ & \\
\hline $\mathbf{1 9 8 8}$ & 1.35 & 0.94 & 1.34 & 0.90 \\
\hline $\mathbf{1 9 8 9}$ & 1.03 & 0.85 & 0.87 & 0.75 \\
\hline $\mathbf{1 9 9 0}$ & 1.04 & 0.83 & 0.89 & 0.72 \\
\hline $\mathbf{1 9 9 1}$ & 1.11 & 0.89 & 1.03 & 0.90 \\
\hline $\mathbf{1 9 9 2}$ & 1.22 & 0.89 & 1.45 & 1.02 \\
\hline $\mathbf{1 9 9 3}$ & 1.27 & 1.32 & 0.83 & 0.75 \\
\hline $\mathbf{1 9 9 4}$ & 0.87 & 0.79 & 0.80 & 0.68 \\
\hline $\mathbf{1 9 9 5}$ & 0.95 & 0.49 & 0.90 & 0.55 \\
\hline $\mathbf{1 9 9 6}$ & 1.20 & 1.25 & 1.06 & 0.82 \\
\hline $\mathbf{1 9 8 8 - 1 9 9 6}$ & $\mathbf{1 . 1 3}$ & $\mathbf{0 . 9 5}$ & $\mathbf{1 . 0 4}$ & $\mathbf{0 . 7 9}$ \\
\hline $\mathbf{1 9 9 7}$ & 1.34 & 1.17 & 1.14 & 0.90 \\
\hline $\mathbf{1 9 9 8}$ & 1.15 & 1.04 & 0.92 & 0.65 \\
\hline $\mathbf{1 9 9 9}$ & 1.11 & 0.72 & 1.18 & 0.56 \\
\hline $\mathbf{2 0 0 0}$ & 1.13 & 1.13 & 1.09 & 1.04 \\
\hline $\mathbf{2 0 0 1}$ & 1.11 & 0.94 & 0.86 & 0.85 \\
\hline $\mathbf{2 0 0 2}$ & 1.32 & 1.42 & 1.44 & 1.40 \\
\hline $\mathbf{2 0 0 3}$ & 1.44 & 1.72 & 1.17 & 0.96 \\
\hline $\mathbf{2 0 0 4}$ & 1.29 & 1.36 & 1.39 & 1.23 \\
\hline $\mathbf{2 0 0 5}$ & 1.49 & 1.64 & 1.43 & 1.29 \\
\hline $\mathbf{1 9 9 7 - 2 0 0 5}$ & $\mathbf{1 . 2 7}$ & $\mathbf{1 . 2 7}$ & $\mathbf{1 . 2 0}$ & $\mathbf{1 . 0 1}$ \\
\hline
\end{tabular}

on the calibration period (versus $1.20^{\circ} \mathrm{C}$ for the EQB model and $1.13^{\circ} \mathrm{C}$ for the SMP1 model) and $1.20^{\circ} \mathrm{C}$ on the validation period (versus $1.31^{\circ} \mathrm{C}$ for the EQB model and $1.27^{\circ} \mathrm{C}$ for the SMP1 model). Results for temperatures above $20^{\circ} \mathrm{C}$ were about the same as those obtained with the EQB model on the calibration period $\left(0.79{ }^{\circ} \mathrm{C}\right.$ versus $0.81^{\circ} \mathrm{C}$ for the EQB model) and were better than with the SMP1 model $\left(0.95^{\circ} \mathrm{C}\right)$. The RMSE ranged for this period between $0.80{ }^{\circ} \mathrm{C}(1994)$ and $1.45{ }^{\circ} \mathrm{C}$ (1992) using all data and from $0.55{ }^{\circ} \mathrm{C}$ (1995) to $1.02{ }^{\circ} \mathrm{C}(1992)$ using temperatures above $20^{\circ} \mathrm{C}$ only. For the validation period the SMPM model clearly provided better results for temperatures above $20^{\circ} \mathrm{C}$, with the RMSE calculated at $1.01{ }^{\circ} \mathrm{C}$ (versus $1.22{ }^{\circ} \mathrm{C}$ for the EQB model and $1.27^{\circ} \mathrm{C}$ for the SMP1 model) and ranging from $0.56{ }^{\circ} \mathrm{C}$ (1999) to $1.40{ }^{\circ} \mathrm{C}$ (2002). Comparison between the EQB model and SMPM model predictions for the years 1992 and 2005 (Figures 4 and 5) clearly showed the better accuracy of the SMPM model at low temperatures. The end of the 2005 time series was particularly better predicted by the SMPM model than by the EQB model. 


\section{Table VII}

RMSE $\left({ }^{\circ} \mathrm{C}\right)$ calculated from observed and predicted daily mean water temperatures using only the seasonal component, the SMP1 model and the SMPM model for the years 1988-2005 in Malause.

\section{Tableau VII}

Erreurs-types $\left({ }^{\circ} \mathrm{C}\right)$ calculées entre les observations des températures moyennes journalières de l'eau et les estimations fournies par la composante saisonnière seulement, le modèle SMP1 ou le modèle SMPM, sur la période 1988-2005.

\begin{tabular}{|l|c|c|c|c|c|c|c|}
\hline & Seasonal component & SMP1 & SMPM & & Seasonal component & SMP1 & SMPM \\
\hline $\mathbf{1 9 8 8}$ & 1.53 & 1.35 & 1.34 & $\mathbf{1 9 9 7}$ & 2.05 & 1.34 & 1.14 \\
\hline $\mathbf{1 9 8 9}$ & 1.60 & 1.03 & 0.87 & $\mathbf{1 9 9 8}$ & 1.55 & 1.15 & 0.92 \\
\hline $\mathbf{1 9 9 0}$ & 2.01 & 1.04 & 0.89 & $\mathbf{1 9 9 9}$ & 1.37 & 1.11 & 1.18 \\
\hline $\mathbf{1 9 9 1}$ & 1.87 & 1.11 & 1.03 & $\mathbf{2 0 0 0}$ & 1.52 & 1.13 & 1.09 \\
\hline $\mathbf{1 9 9 2}$ & 2.31 & 1.22 & 1.45 & $\mathbf{2 0 0 1}$ & 1.90 & 1.11 & 0.86 \\
\hline $\mathbf{1 9 9 3}$ & 1.66 & 1.27 & 0.83 & $\mathbf{2 0 0 2}$ & 1.72 & 1.32 & 1.44 \\
\hline $\mathbf{1 9 9 4}$ & 1.61 & 0.87 & 0.80 & $\mathbf{2 0 0 3}$ & 2.04 & 1.44 & 1.17 \\
\hline $\mathbf{1 9 9 5}$ & 1.62 & 0.95 & 0.90 & $\mathbf{2 0 0 4}$ & 1.54 & 1.29 & 1.39 \\
\hline $\mathbf{1 9 9 6}$ & 1.69 & 1.20 & 1.06 & $\mathbf{2 0 0 5}$ & 2.19 & 1.49 & 1.43 \\
\hline $\mathbf{1 9 8 8 - 1 9 9 6}$ & $\mathbf{1 . 7 8}$ & $\mathbf{1 . 1 3}$ & $\mathbf{1 . 0 4}$ & $\mathbf{1 9 9 7 - 2 0 0 5}$ & $\mathbf{1 . 7 8}$ & $\mathbf{1 . 2 7}$ & $\mathbf{1 . 2 0}$ \\
\hline \multicolumn{7}{|c|}{ Validation period } \\
\hline
\end{tabular}

Figure 4.a

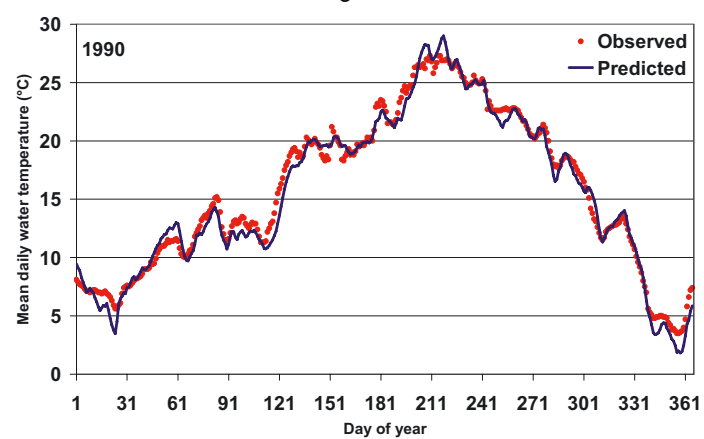

Figure 4.c

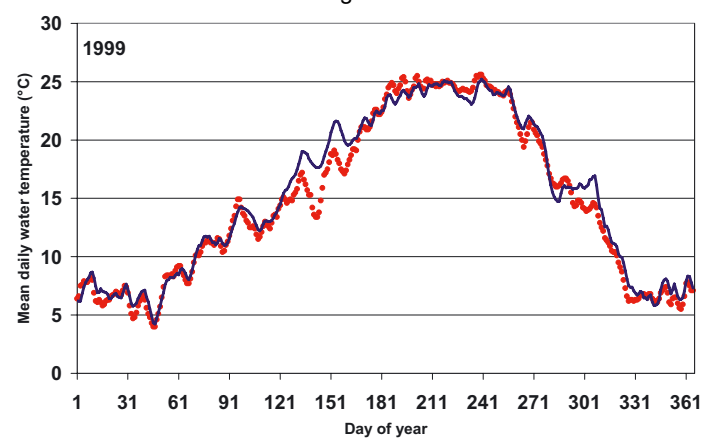

Figure 4.b

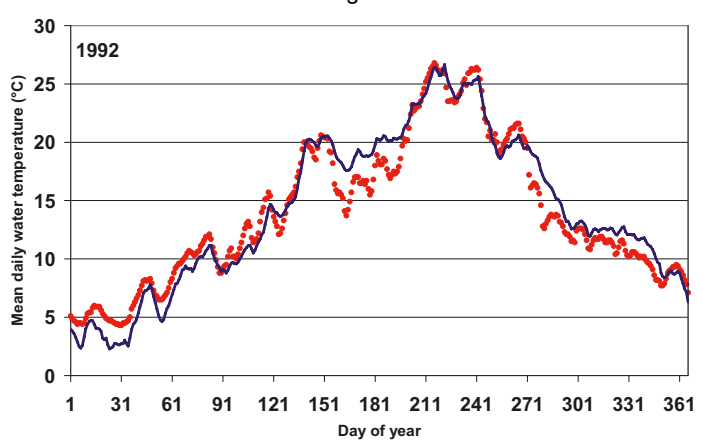

Figure 4.d

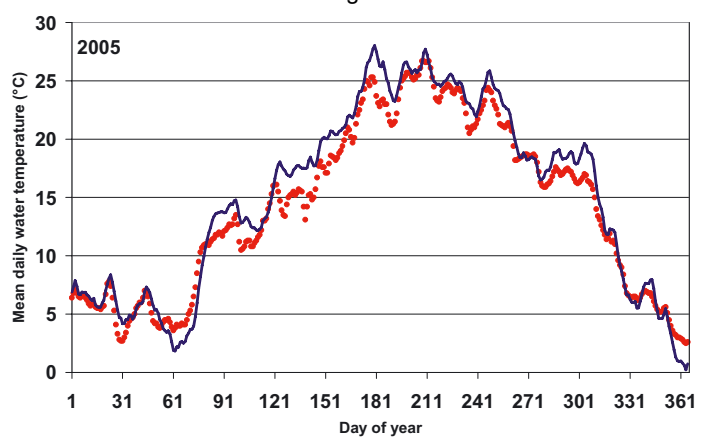

Figure 4

Results for modeling daily mean water temperatures by the EQB model in Malause for both the calibration period (Figures 4.a and 4.b) and validation period (Figures 4.c and 4.d).

Figure 4

Estimations des températures de l'eau à Malause par le modèle EQB, sur la période de calibration (Figures 4.a et 4.b) et sur la période de validation (Figures 4.c et 4.d). 
Figure 5.a

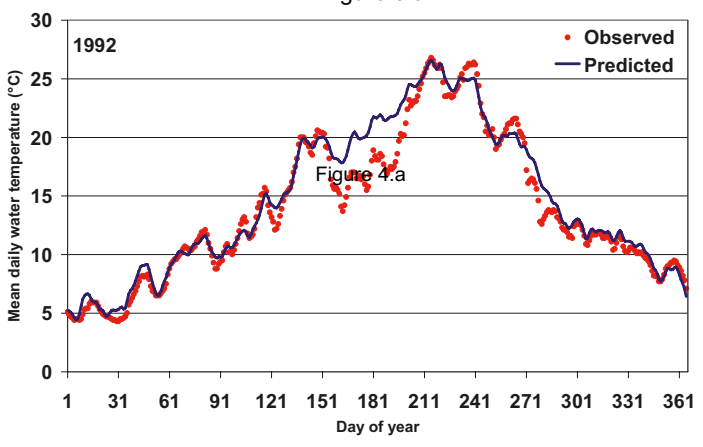

Figure 5.c

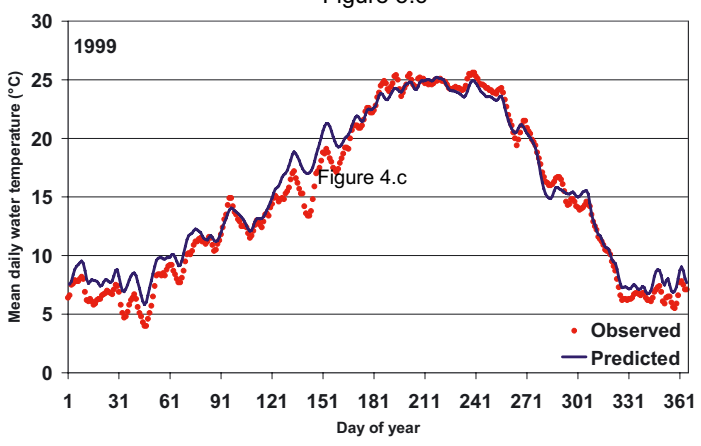

Figure 5.b

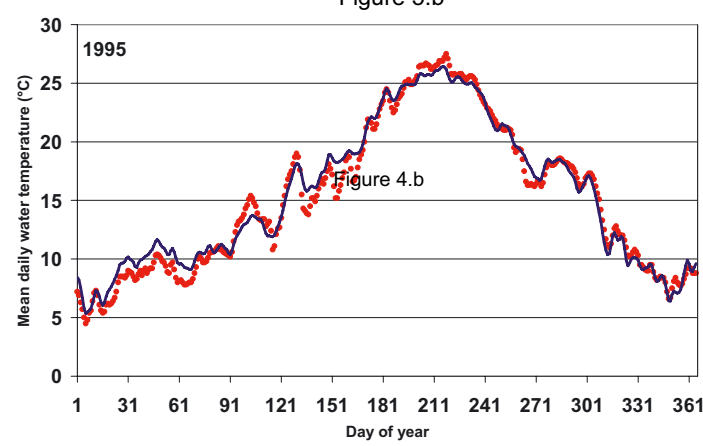

Figure 5.d

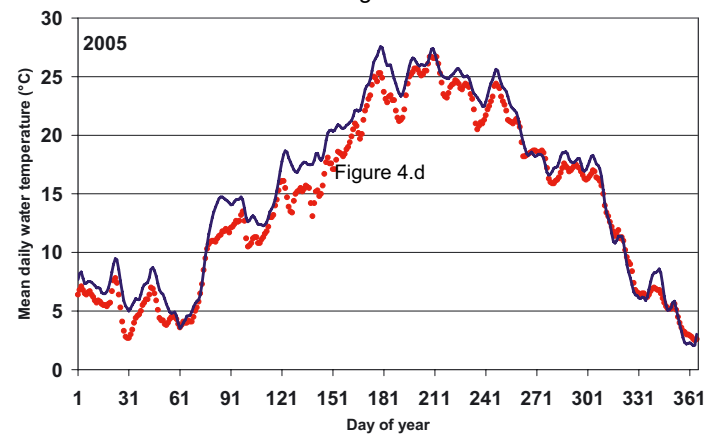

\section{Figure 5}

Results for modeling daily mean water temperatures by the stochastic SMPM model in Malause for both the calibration period (Figures 5.a and 5.b) and validation period (Figures 5.c and 5.d).

\section{Figure 5}

Estimations des températures de l'eau à Malause par le modèle stochastique SMPM, sur la période de calibration (Figures 5.a et 5.b) et sur la période de validation (Figures 5.c et 5.d)

\section{> TEMPERATURE CONDITIONS FOR MIGRATION}

The last evaluation of those models consisted of evaluating their propensity to predict the crossing of the three thresholds of water temperature related to salmon conditions for migration and viability. The time locations of the corresponding periods are plotted in Figure 6. In this figure, short-lasting threshold crossings (less than 7 days) were erased to improve clarity. Both models showed good accuracy, particularly in predicting the $24^{\circ} \mathrm{C}$ threshold crossings. Some large differences were, however, noted, as for the first crossing of the $19{ }^{\circ} \mathrm{C}$ threshold in the year 1999. Distribution of errors between predicted and observed temperature were calculated for each threshold and for days where crossings were not well predicted (Figure 7). Except for the $19{ }^{\circ} \mathrm{C}$ threshold, about $80 \%$ of errors were in the range $\left[-2{ }^{\circ} \mathrm{C} ; 2{ }^{\circ} \mathrm{C}\right]$. For the $9{ }^{\circ} \mathrm{C}$ and $24^{\circ} \mathrm{C}$ thresholds, SMPM performed slightly better with, respectively, $87 \%$ and $84 \%$ of absolute errors less than $2{ }^{\circ} \mathrm{C}$ (versus $82 \%$ and $77 \%$ for the EQB model). On the contrary, the $9{ }^{\circ} \mathrm{C}$ threshold crossing was better predicted by the EQB with $57 \%$ of absolute errors less than $2{ }^{\circ} \mathrm{C}$ (versus $52 \%$ for the SMPM model).

\section{DISCUSSION}

Water temperatures in streams can be related to numerous factors such as climate, hydraulic regimes, bed topography, and others (Caissie, 2006; Webb et al., 2008). Deterministic models using many factors have been used in the literature and proved to efficiently predict water temperatures (Sinokrot and Stefan, 1984; Kim and Chapra, 1997; Webb and Zhang, 1999; 


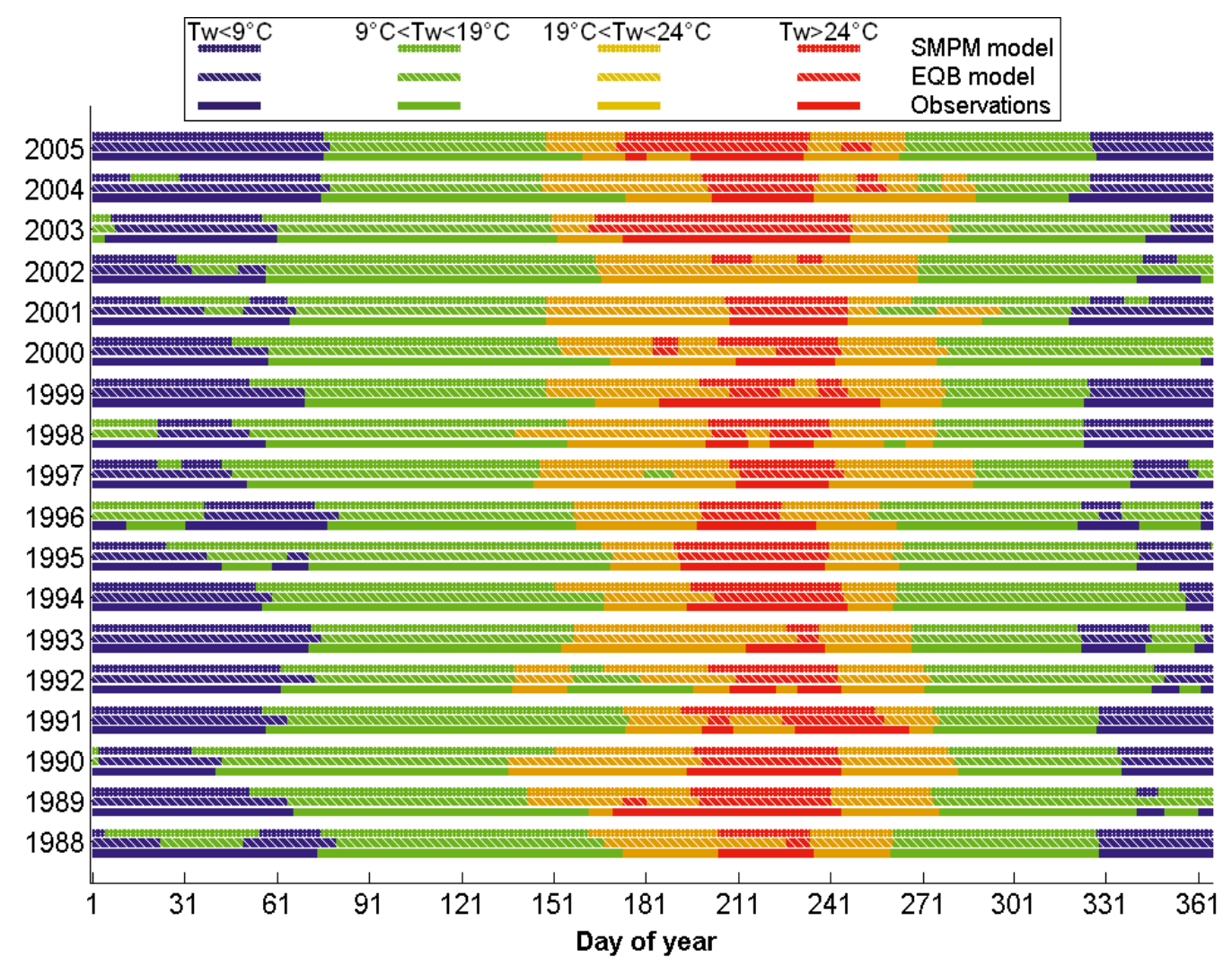

\section{Figure 6}

Comparison between observed and predicted time location of temperature conditions for spawning. Favorable conditions are represented in green.

Figure 6

Comparaison entre les observations et les estimations des occurrences temporelles liées aux conditions de migration. Les périodes favorables sont représentées en vert.

Marcé and Armengol, 2008). Using those models, however, requires lots of data and computational resources. Such models are consequently not easy to use for practitioners. This study was therefore conducted on the Garonne River to assess the performance of statistical models to predict daily mean water temperatures and particularly high temperatures that impact on aquatic ecosystems.

Trend analyses revealed that water temperature evolution was closely similar to that of air temperatures. Similar results were reported for two large rivers in France, the Loire River (Moatar and Gailhard, 2006) and the Rhône River (Poirel et al., 2008). Such similarities tend to indicate that water temperature in large rivers in France is mainly influenced by climatic conditions and particularly air temperatures. Solar radiation was also noted to be correlated with the water temperature but using this factor as a predictor would potentially have resulted in statistical inadequacies associated with multicollinearity. Therefore, using models relying on the relation between air and water temperatures seemed to be accurate for the Garonne River case.

The first model used in this study was based on the equilibrium temperature concept. The equilibrium temperature reflects the energy budget of the stream and therefore is a function of many meteorological factors. It has been shown that the equilibrium temperature could be expressed as a simple linear function of air temperatures for temperate regions (Caissie et al., 2005). This assumption was verified for the Garonne River, with good agreement between air temperatures and the equilibrium temperature $\left(R^{2}=0.99\right)$. The $a_{1}$ coefficient was optimized at a value of 1.12. This value was similar to that reported by Caissie et al. (2005) for the Little 
Figure 7.a

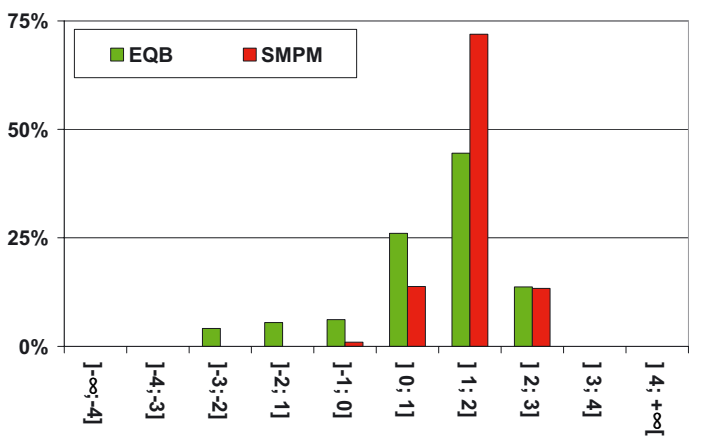

Figure 7.b

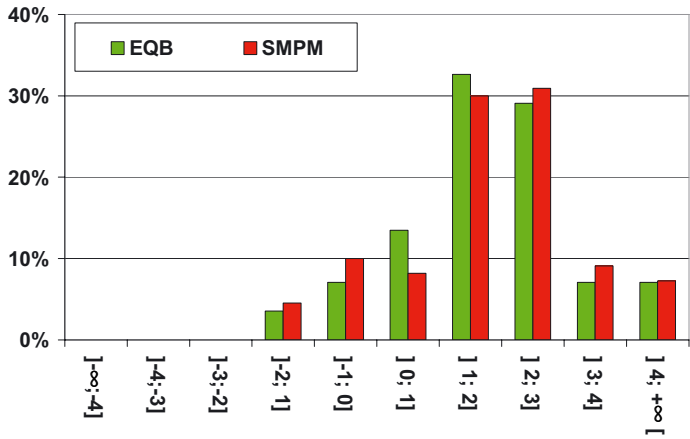

Figure 7.c

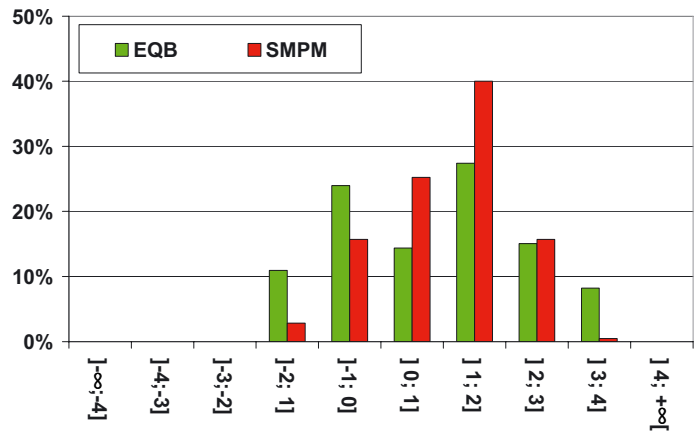

Figure 7

Distribution of discrepancies between predictions and observations for days where crossings of thresholds were not accurately predicted.

\section{Figure 7}

Répartition des erreurs entre estimations et observations pour les jours où les franchissements de seuil ne sont pas correctement reproduits par les modèles.

Southwest Miramichi River (New Brunswick, Canada). Values of this coefficient higher than 1 reflect that the river is well exposed to other meteorological factors than air temperatures (i.e. solar radiation, etc.) which was the case of the Garonne river due to its wideness. The $a_{2}$ coefficient, however, was not zero, which differs from the results reported by Caissie et al. The thermal coefficient $K^{\prime}$ was calculated at 0.71 and agreed with that of the Little Southwest Miramichi River.

The results obtained with the equilibrium-based model were similar to those reported in other studies, with values of RMSE calculated at $1.22{ }^{\circ} \mathrm{C}$ on the calibration period and $1.31{ }^{\circ} \mathrm{C}$ on the validation period. Regarding temperatures above $20^{\circ} \mathrm{C}$ only, slightly better values of $0.81{ }^{\circ} \mathrm{C}$ on the calibration period and $1.22{ }^{\circ} \mathrm{C}$ on the validation period were obtained. This model was therefore sensitive to the data used for calibration. Inter-annual comparison also indicated that estimations for several years were poorly estimated. Except for the year 1988, whose measured water temperature time series contained outliers (caused by measurement failures), correlations between the model residuals and water depths were found to be strong for those years, whereas poor correlations were calculated for years with good results (Table VIII). The EQB model was therefore sensitive to water depths and approximating $B / A$ with $1 / h$ could be debated. Another simplification - neglecting diffusive and convective terms - could also be too restrictive. Significant floods with discharge of more than $5000 \mathrm{~m}^{3} \cdot \mathrm{s}^{-1}$ happen in this river. During such floods, the importance of convective terms must not be negligible.

Stochastic modeling consisted of separating water temperatures and air temperatures into two components: a seasonal component (long-term variations) and residuals (short-term 


\section{Table VIII}

Correlation between the EQB model residuals and water depths.

Tableau VIII

Corrélations entre les résidus du modèle EQB et les hauteurs d'eau.

\begin{tabular}{|c|c|c|c|c|c|}
\hline & Correlation & $p$-Value & & Correlation & $p$-Value \\
\hline $\mathbf{1 9 8 8}$ & -0.19 & 0.000 & $\mathbf{1 9 9 7}$ & -0.11 & 0.044 \\
\hline $\mathbf{1 9 8 9}$ & -0.21 & 0.000 & $\mathbf{1 9 9 8}$ & -0.17 & 0.001 \\
\hline $\mathbf{1 9 9 0}$ & - & 0.389 & $\mathbf{1 9 9 9}$ & 0.11 & 0.041 \\
\hline $\mathbf{1 9 9 1}$ & -0.15 & 0.003 & $\mathbf{2 0 0 0}$ & -0.24 & 0.000 \\
\hline $\mathbf{1 9 9 2}$ & -0.69 & 0.000 & $\mathbf{2 0 0 1}$ & -0.16 & 0.003 \\
\hline $\mathbf{1 9 9 3}$ & -0.57 & 0.000 & $\mathbf{2 0 0 2}$ & -0.19 & 0.000 \\
\hline $\mathbf{1 9 9 4}$ & - & 0.083 & $\mathbf{2 0 0 3}$ & -0.36 & 0.000 \\
\hline $\mathbf{1 9 9 5}$ & - & 0.166 & $\mathbf{2 0 0 4}$ & -0.44 & 0.000 \\
\hline $\mathbf{1 9 9 6}$ & -0.11 & 0.037 & $\mathbf{2 0 0 5}$ & -0.56 & 0.000 \\
\hline \multicolumn{7}{|c|}{ Validation period } & \multicolumn{3}{c|}{ Calibration period } \\
\hline
\end{tabular}

variations). Second-order Fourier series were fitted to inter-annual daily means of water and air temperatures to establish the seasonal components. Values obtained for coefficients of the Fourier series used to model the water and air temperature seasonal component indicated that seasonal amplitude of water temperatures was always higher than that of air temperatures - which reflected the influence of other meteorological factors as reported for the EQB model - and that air temperatures have on average a 7-day delay from water temperatures, which was due to the thermal inertia of the water.

Once the seasonal component was removed from water temperatures, the residuals of water temperature were modeled using two stochastic models. These two models used a secondorder autoregressive model with exogenous variables. The SMP1 only used air temperature residuals as an exogenous predictor, while the SMPM model used lagged (up to 3 days) air temperature residuals. Coefficients of the autoregressive model were calculated using autocorrelation coefficients of the water temperature residuals. Autocorrelation coefficients were similar to those reported for large rivers, for instance $R_{1}=0.84$ in Illinois river, IL, USA (Kothandaraman, 1971) and $R_{1}=0.92$ in the Rivière du Nord near Montreal, P.Q., Canada (Cluis, 1972). Finally, the remaining coefficients of both models were optimized using measured water temperatures above $20^{\circ} \mathrm{C}$.

The stochastic models were more robust than the EQB model due to the fitness of the seasonal curve. As more than $80 \%$ of the variance of water temperature was explained by the seasonal component, the stochastic models' performance mainly depended on the fitness of this component. The SMP1 model performed slightly better than the EQB model when comparing RMSE using all data. On the contrary, RMSE calculated for temperatures above $20^{\circ} \mathrm{C}$ were slightly higher. The results obtained for the SMPM model were on average better than those obtained with the other two models. As for the EQB model, water temperatures for several years were poorly predicted, such as the years 1988 and 1992 in the calibration period and the years 2002, 2004 and 2005 in the validation period. Except for the year 1988 (outliers) the seasonal component for these years were poorly fitted (Table VII), which explained the poor results obtained by the stochastic models.

The performance of the EQB and SMPM models was also tested on predicting the crossing of water temperature thresholds linked to the conditions of Atlantic Salmon. Despite several differences, the models showed good performance. Analyses of errors for days where threshold crossings were not well predicted revealed that most of these errors were in the range $\left[-2{ }^{\circ} \mathrm{C}\right.$; $2{ }^{\circ} \mathrm{C}$ ]. Errors for the $19{ }^{\circ} \mathrm{C}$ crossing were, however, bigger; especially for the SMPM model, that performed more poorly for temperatures just under $20^{\circ} \mathrm{C}$. 


\section{CONCLUSION}

Both approaches used in this study could be useful for practitioners. Despite being applied to a complex study area (reservoir and influence of tributary), these simplified models showed good accuracy in predicting high water temperatures of the Garonne River in Malause. As water and air temperatures are relatively inexpensive to measure, statistical models are good alternatives to deterministic models that require much more data. In our study, equilibrium temperatures were established from meteorological parameters, and values of the linear regression between equilibrium temperatures and air temperatures were calculated afterwards. However, it should be possible to establish the model directly using only air and water temperatures and an optimization method in order to use only air temperatures, water temperatures and water depths. Furthermore, using real values of top width and wetted area or non-linear regression would probably result in better prediction, as well as multiplying each thermal flux by a calibration factor (Caissie et al., 2007) to slightly modify their respective influences. Regarding the stochastic models, performance was mainly dependent on the fitness of the seasonal component. Therefore, further research is needed to explore the advantages of using variable coefficients for this component. Finally, as the meteorological station was located $17 \mathrm{~km}$ downstream of the study site, potential improvements could also be made by alternatively using microclimate data (Benyahya et al., 2010), particularly in determination of heat fluxes for the EQB model.

Each model could have different usage for practitioners. As the EQB predicts water temperatures from climatic conditions, this model could be useful to assess the evolution of the thermal regime of the Garonne River under climate change. Using regional data derived from Global Circulation Model (GCM) outputs, water temperatures could be calculated for future years. On the contrary, the stochastic models used in this study require knowledge of past water temperature values. These models are therefore more suitable for short-term predictions.

\section{REFERENCES}

Ahmadi-Nedushan B., St-Hilaire A., Ouarda T.B.M.J., Bilodeau L., Robichaud E., Thiemonge N. and Bobee B., 2007. Predicting river water temperatures using stochastic models: case study of the Moisie River (Quebec, Canada). Hydrol. Process., 21, 21-34.

Akaike H., 1974. A new look at the statistical model identification. IEEE Trans. Automat. Contr., 19, 716-723.

Alabaster J.S., 1967. The survival of salmon (Salmo salar L.) ans sea trout (S. trutta L.) in fresh and saline water at high temperatures. Water Res., 1, 717-730.

Benyahya L., Caissie D., St-Hilaire A., Ouarda T.B.M.J. and Bobee B., 2007a. A review of statistical water temperature models. Can. Water Resources J., 32, 179-192.

Benyahya L., St-Hilaire A., Ouarda T.B.M.J., Bobee B. and Ahmadi-Nedushan B., 2007b. Modeling of water temperatures based on stochastic approaches: case study of the Deschutes River. J. Environ. Eng. Sci., 6, 437-448.

Benyahya L., Caissie D., El-Jabi N. and Satish M.G., 2010. Comparison of microclimate vs. remote meteorological data and results applied to a water temperature model (Miramichi River, Canada). J. Hydrol., 380, 247-259.

Berger J.O., 1985. Certain Standard Loss Functions. In: Statistical decision theory and Bayesian Analysis, 2nd edn., Springer-Verlag, New York, 60-64.

Caissie D., 2006. The thermal regime of rivers: a review. Freshw. Biol., 51, 1389-1406.

Caissie D., El-Jabi N. and St-Hilaire A., 1998. Stochastic modelling of water temperatures in a small stream using air to water relations. Can. J. Civ. Eng., 25, 250-260.

Caissie D., Satish M.G. and El-Jabi N., 2005. Predicting river water temperatures using the equilibrium temperature concept with application on Miramichi River catchments (New Brunswick, Canada). Hydrol. Process., 19, 2137-2159. 
Caissie D., Satish M.G. and El-Jabi N., 2007. Predicting water temperatures using a deterministic model: Application on Miramichi River catchments (New Brunswick, Canada). J. Hydrol., 336, 303-315.

Chanseau M., Croze O. and Larinier M., 1999. Impact des aménagements sur la migration anadrome du saumon atlantique (Salmo salar L.) sur le gave de Pau (France). Bull. Fr. Pêche Piscic., 353-354, 211-237.

Chenard J.F. and Caissie D., 2008. Stream temperature modelling using artificial neural networks: application on Catamaran Brook, New Brunswick, Canada. Hydrol. Process., 22, 3361-3372.

Cluis D.A., 1972. Relationship between stream water temperature and ambient temperature - a simple autoregressive model for mean daily stream water temperature fluctuations. Nordic Hydrology, 3, 65-71.

Croze O., Blot E., Delmas F., Alesina R., Jourdan H., Bau F. and Breinig T., 2006. Suivi de la qualité de l'eau de la Garonne lors de la migration anadrome du saumon en amont de Golfech. RA06.04, GHAAPE, Toulouse.

Decola J.N., 1970. Water quality requirements for Atlantic salmon. CWT-10-16; PB-230733, Federal Water Quality Administration, Needham Heights, New England Basins Office.

Edinger J.E., Duttweiler D.W. and Geyer J.C., 1968. The response of water temperatures to meteorological conditions. Water Resour. Res., 4, 1137-1143.

El-Jabi N., El-Kourdahi G. and Caissie D., 1995. Modélisation stochastique de la température de l'eau en rivière. Revue des Sciences de l'Eau, 8, 77-95.

Elliott J.M., 1991. Tolerance and resistance to thermal stress in juvenile Atlantic salmon, Salmo salar. Freshw. Biol., 25, 61-70.

Erickson T.R. and Stefan H.G., 2000. Linear air/water temperature correlations for streams during open water periods. J. Hydrol. Eng., 5, 317-321.

Fairchild W.L., Swansburg E.O., Arsenault J.T. and Brown S.B., 1999. Does an association between pesticide use and subsequent declines in catch of Atlantic salmon (Salmo salar) represent a case of endocrine disruption? Environ. Health Perspect., 107, 349-357.

Kim K.S. and Chapra S.C., 1997. Temperature model for highly transient shallow streams. J. Hydraul. Eng., 123, 30-40.

Kothandaraman V., 1971. Analysis of water temperature variations in large river. Journal of the Sanitary Engineering Division-ASCE, 97, 19-31.

Leopold L.B., Wolman M.G. and Miller J.P., 1964. Fluvial process in Geomorphology, W.H. Freeman and Co., San Francisco.

Marcé R. and Armengol J., 2008. Modelling river water temperature using deterministic, empirical, and hybrid formulations in a Mediterranean stream. Hydrol. Process., 22, 3418-3430.

Marcotte N. and Duong V.-L., 1973. Le calcul de la température de l'eau des rivières. J. Hydrol., 18, 273-287.

Moatar F. and Gailhard J., 2006. Water temperature behaviour in the River Loire since 1976 and 1881. C. R. Geosci. , 338, 319-328.

Mohseni O. and Stefan H.G., 1999. Stream temperature air temperature relationship: a physical interpretation. J. Hydrol., 218, 128-141.

Mohseni O., Stefan H.G. and Erickson T.R., 1998. A nonlinear regression model for weekly stream temperatures. Water Resour. Res., 34, 2685-2692.

Morin G. and Couillard D., 1990. Predicting river temperatures with a hydrological model. In: Encyclopedia of Fluid Mechanic, Surface and Groundwater Flow Phenomena, Golf Publishing Company, Houston, 171-209.

Pilgrim J.M., Fang X. and Stefan H.G., 1998. Stream temperature correlations with air temperatures in Minnesota: implications for climate warning. J. Am. Water Resour. Assoc., 34, 1109-1121.

Poirel A., Lauters F. and Desaint B., 2008. 1977-2006 : Trente années de mesures des températures de l'eau dans le Bassin du Rhône. Hydroécol. Appl., 16, 191-213.

Raphael J.M., 1962. Prediction of temperature in rivers and reservoirs. Journal of the Power Division, 88, 157-181.

Sinokrot B.A. and Stefan H.G., 1984. Stream water-temperature sensitivity to weather and bed parameters. J. Hydraul. Eng., 120, 722-736. 
Sinokrot B.A. and Stefan H.G., 1993. Stream Temperature Dynamics - Measurements and Modeling. Water Resour. Res., 29, 2299-2312.

Sinokrot B.A. and Stefan H.G., 1994. Stream water-temperature sensitivity to weather and bed parameters. J. Hydraul. Eng., 120, 722-736.

Stefan H.G. and Preud'homme E.B., 1993. Stream temperature estimation from air temperature. J. Am. Water Resour. Assoc., 29, 27-45.

Swansburg E., Chaput G., Moore D., Caissie D. and El-Jabi N., 2002. Size variability of juvenile Atlantic salmon: links to environmental conditions. J. Fish Biol., 61, 661-683.

Torgersen C.E., Faux R.N., McIntosh B.A., Poage N.J. and Norton D.J., 2001. Airborne thermal remote sensing for water temperature assessment in rivers and streams. Remote Sens. Environ., 76, 386398.

Webb B.W. and Zhang Y., 1999. Water temperatures and heat budgets in Dorset chalk water courses. Hydrol. Process., 13, 309-321.

Webb B.W., Hannah D.M., Moore R.D., Brown L.E. and Nobilis F., 2008. Recent advances in stream and river temperature research. Hydrol. Process., 22, 902-918.

Wilkie M.P., Brobel M.A., Davidson K., Forsyth L. and Tufts B.L., 1997. Influences of temperature upon the postexercise physiology of Atlantic salmon (Salmo salar). Can. J. Fish. Aquatic Sci., 54, 503511. 